\title{
Działalność organizacyjna Karaimów z pierwszej fali emigracji rosyjskiej w przededniu II wojny światowej na podstawie korespondencji z hachanem Serają Szapszałem
}

\author{
Mariola Abkowicz \\ Uniwersytet im. Adama Mickiewicza w Poznaniu \\ Wydział Neofilologii
}

The Organisational Efforts of the Karaims from the First Wave of Russian Emigration on the Eve of the Second World War as Described in the Correspondence with Hachan Seraya Shapshal

Summary: The correspondence of Hachan Seraya Shapshal from the interwar period provides us with new insights into life in the Karaite community in $20^{\text {th }}$-century Europe. The fact that Karaims from the first-wave of the Russian emigration (white émigrés) who settled in Germany and Czechoslovakia were motivated to organise themselves and that their newly-formed groups were subordinate to the hachan of the Republic of Poland were crucial factors that saved the Karaims in Poland and Soviet Union from the Holocaust. In the years 1934-1939, thanks to the efforts of Michal (Musa) Kowszanly, Simon Duwan and Seraya Shapsal the Nazi German authorities introduced regulations classifying Karaims as "Aryan" and thus not subject to the restrictions imposed by the Nuremberg Race Laws.

Keywords: Karaims in Germany, Karaims in Czechoslovakia, Karaims in Romania, Seraya Shapshal, Michal Kowshanly, Karaims and the Nuremberg Laws 
Podjęta w ostatnich latach próba rekonstrukcji procesu uzyskania przez Karaimów statusu nie-Żydów (status der Nichtjuden) przez Hannelore Müller [Müller 2010] w oparciu o materiały z archiwów niemieckich, francuskich i amerykańskich pozostaje niekompletna, pozostawia bowiem znaki zapytania tam, gdzie odpowiedzi można znaleźć w archiwaliach karaimskich. Również Kiril Feferman [Feferman 2011] w swych rozważaniach nie potrafi znaleźć odpowiedzi na pytanie, dlaczego Niemcy nie stosowali w stosunku do Karaimów ustaw norymberskich, i bezpodstawnie oskarża przedstawicieli społeczności karaimskiej o kolaborację z Niemcami w latach 1939-1944 lub doszukuje się przyczyn w bliskich kontaktach z Tatarami, muzułmanami lub Turcją, czy też działalności Stowarzyszenia Tatarsko-Karaimskiego Wiednia w latach 40. XX w.

W dziale rękopisów Biblioteki Wróblewskich Litewskiej Akademii Nauk przechowywane są trzy kolekcje dokumentów karaimskich: F143 Archiwum Seraji Szapszała, F301 Archiwum Karaimskiego Zarządu Duchownego w Trokach oraz F305 Archiwum Szymona Firkowicza. Dokumenty z tych trzech kolekcji stanowią od lat obiekt zainteresowania historyków, językoznawców i literaturoznawców zajmujących się tematyką karaimską. Kwerendy tych archiwaliów prowadzone przez naukowców z Polski, Litwy i Ukrainy pozwoliły odnaleźć wiele dokumentów i odsłonić nowe karty historii społeczności karaimskich lub rzucić światło na znane już fakty z ich dziejów.

W „Almanachu Karaimskim” z roku 2013 została opublikowana korespondencja Ananiasza Zajączkowskiego z Hadży Serają Szapszałem, stanowiąca część kolekcji F143. W zbiorze tym przechowywanych jest m.in. wiele pism oficjalnych i listów prywatnych, które Szapszał otrzymywał, przebywając jeszcze w Rosji, potem w Persji, na Krymie, w Stambule i w końcu w Wilnie. Jego korespondentami byli krewni, przyjaciele, naukowcy, współpracownicy, przedstawiciele organów państwowych, a także członkowie społeczności karaimskiej pochodzący z Krymu, a po I wojnie światowej żyjący w rozproszeniu w całej Europie. Listy te, dotyczące nie tylko wewnętrznych spraw społeczności karaimskiej, lecz również sytuacji politycznej i prawnej w miejscach zamieszkiwania jej przedstawicieli, stanowią niezwykle cenne źródło informacji o wydarzeniach z początku XX w.

Opuszczający półwysep Krymski kadeci, żołnierze i oficerowie carskich armii oraz cywile, po demobilizacji w Stambule (Turcja) i w Ruszczuku (Bułgaria) [Zajączkowska-Łopatto 2011], osiedlali się w pobliżu formujących się centrów białej emigracji. Najlepiej znane i udokumentowane są dwa takie ośrodki karaimskiego osadnictwa: Stambuł, stanowiący najczęściej pierwszy 
przystanek po wyjeździe z Krymu i Paryż, gdzie osiadła stosunkowo liczna grupa Karaimów - wg niektórych źródeł około 400 osób, w latach 40 XX w. Stowarzyszenie Karaimów we Francji liczyło 220 członków [Kefeli 2007, Müller 2010, Feferman 2011]. Droga ze Stambułu do Paryża mogła prowadzić przez Czechosłowację czy Niemcy - jak na przykład w wypadku Josifa Stamboli [Dubiński 2011] lub też Rumunię, jak w wypadku Tamary Duwan [Sulimowicz 2013]. W tych nowych centrach, w ramach szerszej rosyjskiej wspólnoty emigrantów swoje miejsce znajdowali również poszukujący miejsc osiedlenia karaimscy uchodźcy z Krymu [Kaleta 2014 a i b].

Członkowie nowych karaimskich społeczności utrzymywali kontakty zarówno pomiędzy sobą, jak i z karaimskimi skupiskami w Polsce. W korespondencji Szapszała przywiezionej ze Stambułu zachował się list z 15 sierpnia 1922 r. wysłany do niego jako byłego hachama taurydzkiego, z Pragi:

Ваше Преосвященство

Мы, студенты караимы, находящиеся в Чехословакии в Пражских Учебных Заведениях, оторваны от родной нам России и родного нам караимского народа - с которым больше чъм когда, либо чествуем свою духовную связь - поздравляем Вас как гахама - правого и лучшего представителя караимов, с праздником Пасхи шлем вам свои лучшие пожелания. [Maykapar 15.08.1922]

Pod listem widnieje 11 podpisów. Trudno powiedzieć, czy korespondencja miała formę stałej (inne listy się nie zachowały), czy też był to list incydentalny. Bez wątpienia Szapszał utrzymywał kontakty z karaimskimi uchodźcami rozsianymi w skupiskach emigracyjnych w Europie już od początku lat 20. Przed faktycznym objęciem stanowiska hachana karaimskiego w Polsce, w drodze ze Stambułu zatrzymał się w Kiszyniowie [Zajączkowski 30.04.1928], gdzie wizytował tamtejszą gminę karaimską. Korespondował z jej działaczami również w okresie późniejszym. W liście z 9 grudnia 1929 r. od Semiona Kalfy i Izaaka Ajwaza, zarządu Stowarzyszenia Karaimskiego w Kiszyniowie (Directia Comunitati Caraims in Chișinău) [Kalfa 9.12.1929] otrzymał informację o liczebności społeczności tam zamieszkującej (32 osoby), aktualnym zarządzie stowarzyszenia oraz statut karaimskiego stowarzyszenia zatwierdzony przez odnośne władze 22 stycznia $1926 \mathrm{r}$. w tłumaczeniu z języka rumuńskiego [Ustav 22.01.1926]. Już jako hachan Polski odwiedzał skupiska karaimskie w Europie: w Bułgarii [Myśl Karaimska 1936], Jugosławii i Francji 
[Kefeli 2007], wymieniał też z nimi bieżącą korespondencję. Dlatego w odpowiedzi [Chrząstowski 21.08.1939] na zapytanie polskiego Ministerstwa Wyznań Religijnych i Oświecenia Publicznego z 21 sierpnia 1939 r. (wpłynęło 30 sierpnia 1939 r.) był w stanie dokładnie scharakteryzować poszczególne europejskie społeczności karaimskie:

W uprzejmej odpowiedzi na pismo z dn. 21mb V-4032/39 mam zaszczyt posłać do łaskawej wiadomości Ministerstwa poniższe dane odnoszące się do Karaimów osiadłych w Rumunii, Estonii, Bułgarii i Jugosławii

1. W Rumunii mieszka 54 Karaimów, Zamieszkują oni przeważnie w Kiszyniowie (Besarabia). Trudnią się ogrodnictwem, handlem, zaś inteligencja zawodami wolnymi. Są zarejestrowani i oficjalnie zostali uznaniu przez Rząd za oddzielną grupę wyznaniową i narodowościową. Korzystają ze wszystkich praw obywatelskich. W Kiszyniowie znajduje się niestały dom modlitwy oraz cmentarz pozostałe z czasów dawniejszych. Karaimi zamieszkali poza Kiszyniowem, są zaliczani do grupy rzeczonej.

2. W Estonii prawie wyłącznie w jej stolicy znajduje się około 30 karaimów, Jest fabryka tytoniowa własność Karaima. Koło której żywi się połowa ilości powyższej. Inni trudnią się drobnym przemysłem. Nie są oni zarejestrowani jako oddzielna gmina, i są emigrantami z Krymu w większej swej części, zaś w mniejszej - z Polski.

3. W Bułgarii Karaimi stanowią element napływowy: są to emigranci z Krymu, byli obywatele krymscy, przemysłowcy, z zawodów wolnych (dwaj lekarze w służbie państwowej) Skupiają się głównie w Warnie, w mniejszej ilości w Sofii. Liczba ich wynosi 32 osoby. Nie są oddzielnie rejestrowani, lecz otrzymali obywatelstwo wraz z innymi uchodźcami z Rosji.

4. W Jugosławii wszyscy bez wyjątku Karaimi są byłymi oficerami armii rosyjskiej. Liczba ich sięga do 20 osób i prawie wszyscy są w służbie państwowej.

W ten sposób ogólna ilość Karaimów w krajach wymienionych nie przekracza 140 osób i podane liczby odnoszą się do roku 1937.

Wszystkie te grupy Karaimskie jakie i w ogóle wszyscy Karaimi w innych krajach (ok. 400 we Francji, mała grupa w Charbinie, itp.) składające się z przybyszów z Krymu lub Polski podtrzymują stosunki z Karaimami Polskimi, na którego czele stoi ich wspólny Zwierzchnik duchowny. Stosunki te polegają na załatwianiu ich próśb o wydanie różnych zaświadczeń, delegowanie przez hachanat duchownych dla zaspokajania potrzeb religijnych i wydawania odnośnych dokumentów. W krajach bardziej odległych jak np. we Francji każde małżeństwo wśród Karaimów otrzymuje oddzielne zaoczne błogosławieństwo zawsze przez specjalne pismo Hachana za jego podpisem i urzędową pieczęcią. Było 14 wypadków. 
W piśmie przesłanym z Ministerstwa nie pada pytanie o Karaimów zamieszkałych w Niemczech i Czechosłowacji (w tym czasie włączonej już do Rzeszy Niemieckiej). Powody tego trudno wyjaśnić.

Obawy o los tamtejszej kolonii i starania o nadanie Karaimom statusu różnego od Żydów znalazły odzwierciedlenie w korespondencji. W liście z dnia 23 lipca 1934 r. Julia Kowszanły [Kovšanly 23.06.1934] zwraca się do Szapszała jako hachama karaimskiego w Polsce z prośbą o przesłanie oficjalnego pisma wyjaśniającego pochodzenie Karaimów i stwierdzającego, że nie zaliczają się oni do rasy semickiej.

\section{Его Преосвященству Караимскому Гахаму \\ Ваше Преосвященство! \\ Ввиду общаго національного самоопределенія мы принуждены обратиться к Вашему Преосвященству с просьбой, не отказывать нам в любезности разъяснить в офиціальной формъ происхожденіе нашего народа и не- причастность его к семитской расе; разъяснение это нужно будет пред- ставіть в правительственное учрежденіе по сему прошу, если возможно на нъмецком языке или на русском дабы возможно было здъсь перевести на нъмецкій, но не на польском, т. к с перекладом будет здесь весьма за- труднительной такой документ не достигнет нужной цели. \\ Буду Вам крайне благодарна \\ Глубокоуважаемая Вас \\ Юлія Ковшанлы \\ 23 июля 1934 \\ Berlin, Chlburg [Charlottenburg] 4 \\ Mommsenstr 32}

W przechowywanej w archiwum dokumentacji nie zachowała się, niestety, odpowiedź Szapszała.

Latem 1934 r. włoski statystyk i demograf, prof. Corrado Gini zwrócił się do hachana Szapszała z prośbą o wyrażenie zgody na przeprowadzenie wśród Karaimów Polski antropologiczno-demograficznej ekspedycji naukowo-badawczej. Po konsultacjach z polskimi naukowcami (prof. Janem Czekanowskim, prof. Tadeuszem Kowalskim, dr Michałem Reicherem oraz dyrektorem Głównego Urzędu Statystycznego, dr Edwardem Szturm de Sztremem) i dłuższej wymianie korespondencji Szapszał zgody udzielił. Swe wątpliwości i przemyślenia w tej kwestii wyraził w piśmie z 16 lipca 1934 r. skierowanym do Ministerstwa Wyznań Religijnych i Oświecenia Publicznego [Szapszał 16.07.1934]: 
(...) nie wszyscy jednakowoż gorąco polecali tego włoskiego uczonego-demografa, ostatnio zajmującego się studiami i badaniami nad drobnemi ludami wymierającymi Azji (np. Samarytan) i Afryki.

Ponieważ doszły mnie w drodze prywatnej wiadomości, jakoby prof. Gini został poinformowany przez pewnego żyda polskiego o tem, że Karaimi w Polsce rzekomo należą także do ludów wymierających i że temu sprzyjały niepomyślne warunki stworzone przez nasze Państwo w stosunku do swych mniejszości narodowych, w szczególności do Karaimów - przeto w poczuciu obowiązku patriotycznego, pierwotnie postanowiłem choć i w oględnej formie sprzeciwić się przyjazdowi prof. Giniego z jego wielkim sztabem współpracowników (ok. 15 osób), motywując to m.in. moim wyjazdem do Turcji w sierpniu r.b.

Jednakowoż niezwykle usilne nalegania tego uczonego w związku z informowaniem mnie, że jest on osobistym przyjacielem Mussoliniego, obudziły we mnie wątpliwości: czy moja odmowa nie może pociągnąć za sobą choćby minimalnych, niepożądanych konsekwencji dla naszego Rządu?

Sądzę, że zarówno moje osobiste objaśnienia, jak i wskazówki Hazzanów Kienes karaimskich i Zarządów Gmin, tudzież wyniki samych badań prof. Giniego łatwo by mogły obalić i zadać kłam insynuacjom nieznanego mi polskiego żyda.

Jak się miało wkrótce okazać, wyniki badań Giniego [Gini 1936] stały się jednym z ważkich argumentów wysuwanych w skomplikowanym procesie chronienia przedstawicieli i całych społeczności karaimskich przed skutkami narodowościowej polityki nazistowskiej.

W tym czasie posiadający już pełnię władzy w Niemczech Adolf Hitler rozpoczął unifikację związków wyznaniowych zgodnie z doktryną narodowego socjalizmu. Po uchwaleniu 15 września 1935 r. norymberskich ustaw rasowych i wprowadzeniu pojęcia pochodzenia aryjskiego w prawie niemieckim, a następnie stopniowego wprowadzania przepisów wykonawczych, oficjalna odpowiedź na pytanie, jaka jest przynależność rasowa Karaimów, stała się krytycznie istotna. Społeczność karaimska w Niemczech, złożona z tych, którzy po roku 1920 zaczęli tam właśnie budować swoje nowe życie na uchodźstwie, nie była liczna. Składało się na nią około jedenastu osób, w większości byłych wojskowych, którzy utrzymywali się głównie z pracy fizycznej. Byli wśród nich kelner, szef kuchni, zecer, garderobiany w teatrze, szoferzy, ślusarz, kowal, krawcowa, elektromonter. $\mathrm{Na}$ ogół nie uczestniczyli aktywnie w politycznym życiu białej emigracji, lecz jako byli obywatele rosyjskiego imperium podlegali rejestracji w Komitecie Rosyjskim (niem. Russische Vertrauensstelle), działającym od roku 1934, którego zadaniem był nadzór nad wychodźcami z Rosji niezależnie od ich narodowości i posiadanego obywatelstwa [Doklad 1943]. 
Karaimi berlińscy uznali, że bez względu na ich niewielką liczebność utworzenie Berlińskiego Stowarzyszenia Karaimskiego, lokalnej organizacji, której zadaniem było reprezentowanie społeczności wobec niemieckich władz państwowych, w tym podejmowanie starań o uregulowanie statusu prawnego ludności karaimskiej, stało się celowe i niezbędne dla dalszego funkcjonowania, bowiem skuteczność ich działań indywidualnych nie dawała wystarczających efektów. Założyciele stowarzyszenia berlińskiego wnioskowali również o przyłączenie do karaimskich struktur ogólnych. Nie istniała, co prawda, żadna wyższa organizacja jednocząca karaimskie organizacje narodowe, czy to religijne, czy świeckie, jednak uznanie zwierzchności hachana w Polsce wzmocniłoby pozycję organizacji w Niemczech i pozwoliło na skuteczniejsze prowadzenie działań z wykorzystaniem możliwości europejskich środowisk karaimskich. Szapszał, łączący funkcje tytularnego hachama taurydzko-odeskiego dla uchodźców z Rosji z funkcją hachana Rzeczpospolitej Polskiej, byłby elementem łączącym i dającym oparcie prawne. Jego autorytet osobisty oraz powaga pełnionych przezeń urzędów, zdaniem korespondentów, miały pomóc w uporządkowaniu statusu Karaimów niemieckich w nowej sytuacji prawnej, którą przyniosły ustawy rasowe [Kovšanly 26.06.1936]:

Берлинъ, 26 июля 1936

Его Высокопреосвященству Гахану Караимскому

Ваше Высокопреосвященство!

Мы, проживающіе въ Берлине караимы, несмотря на нашу малочисленностъ решили объединится въ Берлинское Караимское Общество, а вмъстъ с этимъ просит Васъ о формальномъ присоединеніи ко Всеобщей Караимской Общине, которую Вы возглавляете, т. е. об утвержденіи Вашим Высокопреосвященствомъ нашего Общества и его уполномоченного Михаила-Мусса Ковшанлы.

Помимо этого, обстоятельства принуждаютъ нас затруднитъ Ваше Высокопреосвященство еще и следующей просьбой:

Вопросъ о расовомъ происхожденіи, являющійся рбшающим моментом в определеніи прав каждого живучего в Германіи, ставитъ часто насъ, караимов, проживающих здъсъ, въ оченъ тяжелое положеніе, т.-к. незнакомство не только отдъльныхъ чиновниковъ, но и офиціальныхъ правительственныхъ учрежденіи в Германии с вопросом: «Кто такіе Караимы?» приводитъ къ ошибочному причисленію Караимского народа, а следовательно и каждого изъ насъ въ отдъльности, къ іудеям какъ въ расовом какъ и въ въроисповъдномъ отношеніи. Этому способствуютъ напр. «энциклопедическіе»/!? словари, къ которымъ незнающій обращается за помощью. 
Посльдствія такого смъшиванія съ евреями - ограниченія въ правожительстве, въ разръшеніи на работу и права состоятъ в профессіональных союзахъ, безъ чего, в сущности, невозможно получитъ постоянное занятіе итд, - словомъ, уничтоженіе возможности существоватъ. Всё это - нисколько независимо отъ подданства или религіозныхъ убъжденій, ибо, как сказано ръшающее значеніе придаются расовому вопросу, гдъ первое и главное разделение ест: еврей и не-еврей, разделение на германскихъ гражданъ и иностранцев сльдует на 2-мь месте: так. обр., напр., иностранецъ не-еврей в нынешней Германіи значительно правоспособнее немца-еврея.

Каждый изъ насъ въ отдельныхъ случаяхъ защищаетъ свои права, достигая иногда частичного успъха, частичного - ибо объясненія, которые даёт тотъ или иной изъ насъ или указанія на случайные заметки в газетахъ и журналахъ, касающіеся въ сколь вопроса о родственности Караимовъ тюркскому племени, недостаточны и необходимо авторитетное (хотя-бы и краткое) заявленіе по этому вопросу, т-е объясненіе тюркского нашего происхожденія (т.-е. Крымскихъ и Трокскихъ Караимов), дабы представитъ таковое въ расовый отдълъ германского министерства внутр[еннихъ] дъл, и такимъ образомъ попытаться воспрепятствоватъ примененію въ отношеніи проживающихъ в Германіи Караимов §§ законовъ, существующихъ для семитовъ-иудеев.

Поэтому проживающіе въ Берлинъ караимы рбшили обратится къ Вамъ, Ваше Высокопреосвященство, съ просьбой прислать краткую справку о происхожденіи Караимов, которую мы могли бы предъявить германским властям, а также указать намъ законодательные акты или официальные разъяснения как бывш[его] Императорского, такъ и нынъшнего польского правительства по этому вопросу, на которые мы могли бы здъсь ссылаться.

Кромъ того мы просимъ Васъ прислатъ что-либо изъ печатныхъ трудовъ о Караимском народъ, предпочтительно Вашего собственного сочиненія, равно какъ и указатъ заслуживающіе труды на Русском, нъмецком, польскомъ или иномъ языкахъ на эту тему.

Съ глубокимъ уважениемъ

Берлинское Караимское Объединеніе

Предсьдателъ: Муса Ковшанлы

Аронъ Рофе

Александръ Сарибанъ

Семенъ Рофе

Илья Леви

Юлия Ковшанлы

Авадья Рофе 
Można tylko domniemywać, że podjęte działania były wcześniej omawiane i ustalane podczas spotkań osobistych - Julia Kowszanły z synem Michałem gościła u rodziny w Wilnie w czerwcu 1936 r. [Szpakowski 1936].

W styczniu 1938 r. na ręce Szapszała wpłynęła petycja z Besarabii (Rumunii) [Petycja 1938] z prośbą o przyjęcie pod opiekę. Prośba, napisana w imieniu 50 Karaimów, wiązała się z wprowadzeniem również w Rumunii prawa rasowego i związanego z tym faktem zagrożenia dla członków lokalnej społeczności karaimskiej (artykuł 5 Zarządzenia nr 169 z 21 stycznia 1938 r.)

Na początku 1939 r. wpłynęło inne pismo [Bakkal 23.02.1939] dotyczące lokalnego stowarzyszenia, tym razem skierowane przez Karaimów z Pragi w imieniu własnym i rodaków z Brna. Zdając relację z zebrań odbytych w dniach 10 i 20 lutego, zwracali się z prośbą o aprobatę hachana Seraji Szapszała, jako duchowego i narodowego przywódcy Karaimów, dla powołania w Czechosłowacji karaimskiego stowarzyszenia. Jego założycielami było dziewięciu Karaimów mieszkających w Pradze, sześciu z Brna i jeden z Pilzna.

Impulsem dla utworzenia stowarzyszenia była świadomość, że w niedługim czasie czescy Karaimi będą postawieni przed koniecznością odpowiedzenia miejscowym władzom na pytania „1. o naszej religii, 2. o naszym pochodzeniu, 3. o czystości pochodzenia”. Dlatego poprosili o „oficjalne poparcie do punktu pierwszego, że karaimska religia jest oparta o Stary Testament, całkowicie samodzielna, niezależna i niezwiązana z jakąkolwiek inną religią, do punktu drugiego że Karaimi należą do narodu od najdawniejszych czasów zamieszkujących na Krymie, rodzimy język Karaimów należy do rodziny języków turecko-tatarskich, przy czym całkowicie niezależny i od nikogo nie wzięty, do punktu trzeciego co jest bardzo ważne - prosimy o potwierdzenie, że Karaimi od kilku wieków nie uznają neofitów i nawet nie przyjmują do swego środowiska potomstwa z małżeństw mieszanych z innowiercami, jako że faktycznie ślubów takich karaimski kościół nie błogosławi, w ten sposób u Karaimów nie może być innej krwi niż karaimska" [Bakkal 23.02.1939].

Kolejna prośba zawarta w tym samym piśmie dotyczyła udzielenia informacji o materiałach „z których widać, że przez cały czas i we wszystkich państwach Karaimi korzystali z wszystkich praw obywatelskich na równi z innym obywatelami zgodnie z ich stanem posiadania i nawet często z niektórymi przywilejami”.

„(...) znając Waszą stałą troskę i opiekę, jaką darzy Pan swój naród my pozwalamy sobie wierzyć, że nie odmówi Pan naszej pokornej prośbie i mamy nadzieję, że w miarę Pana możliwości będzie Pan mógł szybko odpowiedzieć na naszą prośbę jako, że niedługo problem ten będzie bardzo poważny i nasila się z każdym dniem” - pisali. 
Aktywność liderów karaimskiej społeczności w Berlinie, a także tych we Francji i Polsce, podejmowane działania formalno-organizacyjne, kompletowanie informacji oraz literatury dotyczącej etnicznego pochodzenia Karaimów przyniosły oczekiwane rezultaty. Z listu mieszkającego w Berlinie Aleksandra Saribana [Sariban 28.02.1939] z dnia 28 lutego 1939 r. dowiadujemy się, że 22 grudnia 1938 r. Niemieckie Ministerstwo Spraw Wewnętrznych wydało zarządzenie stwierdzające, że Karaimów jako grupy religijnej nie należy zaliczać do Żydów. Pismo w tej sprawie zostało przekazane na ręce Simona Duwana, w końcu 1938 r. przebywającego czasowo w Berlinie [Müller 2010, 131-132].

Następstwem tego faktu była intensywnie prowadzona od początku lutego do końca sierpnia, jak też jeszcze we wrześniu, korespondencja pomiędzy członkami stowarzyszeń lokalnych a kancelarią hachana Szapszała, dotycząca kompletowania odpowiednich dokumentów. Zgodnie z obowiązującymi przepisami każdy bowiem musiał osobiście udowodnić nieżydowskie (aryjskie) pochodzenie, przedstawiając odpowiednie dokumenty, takie jak świadectwa metryczne, świadectwa ślubu rodziców, dziadków. Jako że emigranci takiej dokumentacji często nie posiadali, a sprowadzenie dokumentów z miejsca urodzenia (Krymu, Ukrainy czy Rosji) nie było na ogół możliwe, jedynym sposobem było wystawianie odpowiednich duplikatów dokumentów i świadectw przez jedynego w Europie karaimskiego zwierzchnika religijnego, hachana Szapszała. Jednakże on również nie posiadał wglądu do dokumentów metrykalnych Hachamatu Odesskiego i Taurydzkiego. Dlatego każdy indywidualnie zwracający się o wystawienie zaświadczenia o karaimskim pochodzeniu, opisywał swoją sytuację bytową, losy od roku 1921 do chwili obecnej, powiązania rodzinne, załączając do prośby posiadane dokumenty, przedstawiając genealogie i powołując na świadków krewnych i znajomych z miejsca obecnego zamieszkania, jak też z innych miejsc, gdzie wcześniej mieszkał. Jako pierwszy z prośbą tego rodzaju wystąpił Aleksander Sariban [Sariban 1.03.1939]. Do swego podania z 1 marca 1939 r. załączył wzór zaświadczenia w języku niemieckim i rosyjskim:

\section{УдостовЂреніе (или: Свидътельство)}

Настоящимъ удостовЂряется для офиціальной надобности, что проживающій въ Берлине Александр Сарибанъ, родившийся 28.5.06 въ Одессъ, по происхожденію своему принадлежитъ къ тюрко-караимскому племени (или просто: къ тюркской народности. А.С.), а по религіи - къ караимскому въроисповъданію.

Онъ является сыномъ инженера Михаила Сарибанъ (род. въ Одессъ, в августъ 1881 г.) и его законной жены, урождённой Кефели (род. 31 января 
1881 г. в Бахчисараъ), оба они также принадлежать теперь какъ и прежде къ караимскому въроисповъданія, а в отношении рассоваго происхождениія - тюрко-караимы. Т.к. родители Александра Сарибан - двоюродные брат и сестра, то в числе его предков лишь три четы прародителей.

Всъ они - представители того же тюрко-караимскаго племени (о чём можно заключить и по исконно тюркскимъ фамиліям ихъ - см. ниже), всъ были караимами по своему вероисповеданію и, равно какъ и дъти ихъ - оба дъда и обе бабушки Александра Сарибанъ - всъ похоронены на караимских кладбищах: частью ъ Бахчисараъ и Мелитополь (Крым), частью въ Одессъ.

Фамиліи трёх прадъдовъ суть: Соотвътствующія дъвичьи фам. прабабок Кефели

Эринчекъ (предполагается возможностъ установитъ)

Сарибанъ Танагозъ (предполагается возможностъ установитъ)

Zaświadczenia podobne do wystawionego dla Aleksandra Saribana, okazały się niezbędne również dla przedłużających prawo pobytu w Berlinie Arona (Arnolda) Rofe [Rofe 13.02.1939], Abadii Rofe [Rofe 13.02.1939] oraz Ilii Lewi-Eru [Levi-Eru 1939]. Musieli oni udowodnić policji, że faktycznie są Karaimami, a także ich „rodzice i prarodzice byli całkowicie Karaimami”. Ilia Lewi-Eru pisał, że jeśli nie przedstawi takiego dokumentu jak bracia Rofe, to nie tylko będzie uznany za Żyda, ale zostanie oskarżony o próbę oszukania policji przez przedstawianie się jako Karaim [Levi-Eru 1939].

Niedługo po wystawieniu pierwszego zaświadczenia dla Aleksandra Saribana przyjęto ustandaryzowaną formę zaświadczenia wydawanego w języku niemieckim i rosyjskim lub lokalnym (polskim, ukraińskim):

Niniejszym zostało wydane na dowód, że Pan zamieszkały $\mathrm{W}$ urodzony w dnia

jest wyznania karaimskiego i pochodzenia karaimsko-tureckiego. Ojciec i matka małżonkowie ślubni, jak i ich przodkowie byli pochodzenia karaimskiego, co stwierdza się własnoręcznym podpisem i przystawieniem pieczęci urzędowej.

W okresie od lutego do sierpnia 1939 r. wpłynęło 35 podań wraz z dokumentacją osobistą i tyle też wysłanych zostało zaświadczeń do Pragi (20), Brna (5), Pilzna (1), Dvůr Královégo (2), Ołomuńca (1), Mernika koło Vranova nad Toplou (1), Warny (2), Hagi (1). Początkowo zaświadczenia nie były wysyłane od razu, ale 
w kwietniu 1939 r. zaczęto robić to natychmiast po otrzymaniu prośby, często jeszcze tego samego dnia. Gdyż, jak pisano z Czechosłowacji, „zaświadczenia są absolutnie niezbędne każdemu z nas dla uzyskania możliwości dalszego istnienia" [Kalfa 11.08.1939].

Ostatnie wpisy w dzienniku korespondencji za rok 1939, pochodzące z września, poświadczają wystawienie zaświadczeń w podanej wyżej standardowej formie dla Karaimów mieszkających w Warszawie. Trocki ułlu hazzan Szymon Firkowicz wnioskował o zaświadczenie dla siostry, Doroty Nowickiej i jej córki, Tairy Aldony Pileckiej. Nadzieja Zajączkowska - dla siebie oraz męża, prof. Ananiasza Zajączkowskiego. Zaświadczenia wystawiono także dla Isaja Pileckiego, Anny Michajłowicz, Michała Maszkiewicza (ryc. 1), Isai Jutkiewicza, Nadziei Jutkiewicz, Zofii Nowickiej i jej córki, Anny Nowickiej. Ostatnie zaświadczenie, którego kopia przechowywana jest w zbiorach Biblioteki Wróblewskich, zostało wystawione 29 września 1939 r. dla Simy (Simona) Kalfe zamieszkałego w Chișinău (Kiszyniowie, Rumunia) [Kalfe 29.09.1939]. Kolejne zaświadczenia już podczas okupacji Szapszał wystawiał osobom, które nie mogły się zwrócić o wystawienie do hazzana właściwej gminy (ryc. 2).

Podczas okupacji niemieckiej ustandaryzowane zaświadczenia w językach niemieckim i litewskim (Troki, Wilno, Poniewież) oraz polskim (Łuck, Halicz) były wystawiane przez hazzanów właściwych kienes na podstawie zapisów w prowadzonych przez nich księgach metrykalnych (ryc. 3).

Działania organizacyjne podjęte w roku 1934 przez Karaimów - wychodźców z Krymu zamieszkujących w Berlinie, przy wsparciu rodaków z Francji, szczególnie Simona Duwana, wsparte autorytetem hachana Seraji Szapszała bez wątpienia w głównej mierze przyczyniły się do uniknięcia przez Karaimów skutków nazistowskiej polityki i jej norymberskich ustaw rasowych oraz przetrwania ich jako grupy etnicznej i wyznaniowej w czasie II wojny światowej. Dzięki wczesnemu zwróceniu uwagi na zagrożenia, jakie niosła polityka rasowa faszystowskich Niemiec, Karaimom w Czechosłowacji, Rumunii, Holandii, Bułgarii udało się szybko i sprawnie zorganizować, a uznanie przez nich zwierzchnictwa Seraji Szapszała jako autorytetu religijnego i narodowego pozwoliło na włączenie ich pod jurysdykcję Karaimskiego Związku Religijnego w RP, przez co udokumentowanie pochodzenia, a tym samym uniknięcie prześladowań, stało się możliwe.

Warto w tym miejscu wspomnieć, choć nie jest to zasadniczym tematem tego artykułu, o roli, jaką w uznaniu nieżydowskiego pochodzenia Karaimów odegrały prowadzone przed wojną badań antropologiczne Juliana Talko-Hryncewicza (1904), Witolda Schreibera (1910 a i b), Michała Reichera (1932), Corrado 
Giniego (1936), Salomona Czortkowera (1938). Były one kontynuowane także podczas okupacji przez nazistowskich badaczy w Trokach i Poniewieżu oraz w Rydze (Steiniger 1944 a i b). Istotnym argumentem były również przedwojenne badania i publikacje polskich orientalistów turkologów, takich jak prof. Tadeusz Kowalski, prof. Ananiasz Zajączkowski i samego Seraji Szapszała, znane i cenione przez niemieckich turkologów (jak np. Anne-Marie von Gabain). O uratowaniu Karaimów przed zagładą powstało wiele twierdzeń, czasem o charakterze niemal legendarnym, wskazywano np. na żydowskiego historyka Majera Bałabana lub muftiego Jakuba Szynkiewicza jako „wybawców”. Należy je jednak traktować jedynie jako legendy, nie znajdują bowiem pokrycia w dokumentach, z których jasno wynika, że decydującą rolę odegrały tu starania i zabiegi samych Karaimów.

Na przetrwanie narodu karaimskiego złożyło się wiele działań osób indywidualnych także podczas wojennej okupacji terytoriów Polski i Związku Sowieckiego, gdyż niezależnie od uchwalonych niemieckich przepisów rozdzielających prawo do życia Karaimów i Żydów i wyłączających Karaimów spod niemieckiego prawa rasowego, należało potwierdzać indywidualną przynależność każdego z osobna do społeczności karaimskiej [Kropotov 2004].

\section{Bibliografia}

\section{Opracowania}

Czortkower, S., 1938, Die Abstammung und Rassenstruktur der Karaimen, „Przegląd Antropologiczny", 12, s. 678-680.

Dubiński, A., 2011, Fortuna kolem sie toczy, „Awazymyz”, 3 (32), s. 4-11.

Feferman, K., 2011, Nazi Germany and the Karaites in 1038-1944: between racial theory and Realpolitik, „Nationalities papers”, 39 (2), s. 277-294.

Gini, C., 1936, I Caraimi di Polonia e Lituania, „Genus”, t. 2., nr 1/2, s. 1-56.

Kaleta, P., 2014a, Karaimové jako součást ruské emigrace v meziválečném Československu, „Český Lid”, t. 101, nr 3, s. 257-277.

Kaleta, P., 2014b, Mój Ojciec pochodził z Eupatorii. Wybitny czeski pisarz Michal Ajvaz opowiada o swoich karaimskich korzeniach”, „Awazymyz”, 1 (42), s. 12-14.

Kefeli, M., 2007, Karaimi we Francji, „Awazymyz”, 3 (17), s. 3-9.

Kropotov, V.S., 2004, Voennye tradicii krymskih karaimov, Doliâ, Simferopoĺ.

Müller, H., 2010, Religionswissenschaftliche Minoritätenforschung: Zur religionshistorischen Dynamik der Karäer im Osten Europas, Harrassowitz Verlag, Wiesbaden.

Reicher, M., 1932, Sur les groupes sanguins des Caraïmes de Troki et de Wilno, „Anthropologie", 10, s. 259-267. 
Schreiber, W., 1910, Zur Anthropologie der Karaimkinder Galiziens, „Archiv für Anthropologie”, 37 (t. 9 serii nowej), s. 64-74.

Schreiber, W., 1910, Badania nad antropologia dzieci chrześcijańskich, żydowskich i karaimskich $w$ Galicyi, Prace Towarzystwa Naukowego Warszawskiego nr 4, Warszawa.

Steiniger, F., 1944a, Bilder von Karaimen und Tataren im Ostland, „Natur und Volk”, 74 (1/2), s. $39-48$.

Steiniger, F., 1944b, Bilder von Karaimen und Tataren im Ostland, „Natur und Volk”, 74 (3/4), s. $78-83$.

Sulimowicz, A., 2013, Artystka niestała w uczuciach: Tamara Duwan, „Awazymyz”, 4 (41), s. 4-7.

Talko-Hryncewicz, J., 1904, Karaimi vel Karaici litewscy. Zarys antropologiczno-etnologiczny, Materjały Antropologiczno-Archeologiczne i Etnograficzne Akademji Umiejętności w Krakowie, nr 7, s. 44-100.

Zajączkowska-Łopatto, M.-E., 2011, Droga Jerzego Łopatto, „Awazymyz”, 4 (33), s. 4-8.

\section{Inne}

1935-1936, Grupa Karaimów w Warnie (Bułgaria): Pośrodku: J. E. Hachan H. S. Szapszał [fotografia], „Myśl Karaimska”, z. 11, s. 121.

\section{Źródła}

Materiały archiwalne z Biblioteki Wróblewskich Litewskiej Akademii Nauk w Wilnie (BWLAN ) oraz Archiwum Akt Nowych w Warszawie (AAN):

1926, Ustav Obŝestva „Obŝina Karaimov goroda Kišineva-Bessarabíâ” s glavnom učreždeníem v étom godu. Perevod s rumynskago, Kišinev, BWLAN F143-360, dok. 2r-4v. 1938, Petycja Karaimów rumuńskich o objęcie opieką, BWLAN F143-1061, dok. 1r-5r.

1943, Doklad o položenii sostoâniâ karaimov v period suŝestvovaniâ nacional-socialističeskogo režima v Germanii i vo vremâ vojny s 1939 goda do nastoâŝego vremeni v zanâtyx' Germaniej stranax na Zapade i Vostoke, BWLAN F143-1053, dok 5r.

Bakkal, S., et al., 1939, List od grupy Karaimów zamieszkujących w Czechosłowacji, Korespondencja Hachana za rok 1939, BWLAN F143-1064/1, dok. 2r-3v.

Chrząstowski, Z., 1939, Pismo do hachana JE Seraja Szapszała, Korespondencja Hachana za rok 1939, BWLAN F143-1064/2, dok. 161r.

Kalfa, G., 1939, List do JE Seraja Szapszała, Korespondencja Hachana za rok 1939, BWLAN F143-1064/2, dok. 122r.

Kalfa, S., Ajvaz, I., 1929, List do S. Szapszała, Korespondencja z Kiszyniowa, BWLAN F143-360, dok. 1r.

Kalfe, S., 1939, Zaświadczenie o pochodzeniu, Korespondencja Hachana za rok 1939, BWLAN F143-1064/2, dok. 184r.

Kovšanly, J., 1934, List do JE Seraja Szapszała, BWLAN F143-393, dok. 1r. 
Kovšanly, M., 1936, List do JE Seraja Szapszała, Korespondencja z Karaimami berlińskimi (1936-1944), BWLAN F143-1053, dok. 1rv.

Levi-Eru, I., 1939, List do JE Seraja Szapszała, Korespondencja Hachana z niemieckimi i czeskimi Karaimami dot. metryk, BWLAN F143-1068, dok. 10rv.

Maykapar, B., i in. 1922, List z Pragi, BWLAN F143-973, dok 1r.

Rofe, A., 1939, List do JE Seraja Szapszała, Korespondencja Hachana za rok 1939, BWLAN F143-1064/2, dok. 119r.

Rofe, A., 1939, List do JE Seraja Szapszała, Korespondencja Hachana za rok 1939, BWLAN F143-1064/1, dok. 45r.

Sariban, A., 1939, List do JE Seraja Szapszała, Korespondencja Hachana za rok 1939, BWLAN F143-1064/1, dok. 41rv.

Sariban, A., 1939, List do JE Seraja Szapszała, Korespondencja Hachana za rok 1939, BWLAN F143-1064/1, dok. 38rv.

Szapszał, S., 1934, Pismo do Dyrektora Departamentu Wyznań Religijnych, Ministerstwo Wyznań Religijnych i Oświecenia Publicznego, AAN MWRIOP sygn. 1464, k. 44rv.

Szapszał, S., 1939, Pismo do Ministerstwa Spraw Wewnętrznych i Oświecenia Publicznego (brudnopis), Korespondencja Hachana za rok 1939, BWLAN F143-1064/2, dok. 158r-160r.

Szpakowski, S., 1936, Oświadczenie o przyjęciu na utrzymanie podczas gościny Julii Kowszanły i Michała Kowszanły z 25 maja 1936 r. oraz dwa oświadczenia o wiarygodności stwierdzenia od pracodawcy i Prezesa Zarządu Gminy w Wilnie, Zaświadczenia i wszelkie dokumenty dla członków gminy, BWLAN F143-981, dok. 69rv.

Zajączkowski, I., 1928, List do S. Szapszała, Korespondencja dot. przyjazdu S. Szapszała do Wilna w 1928, BWLAN F143-714, dok 2rv. 


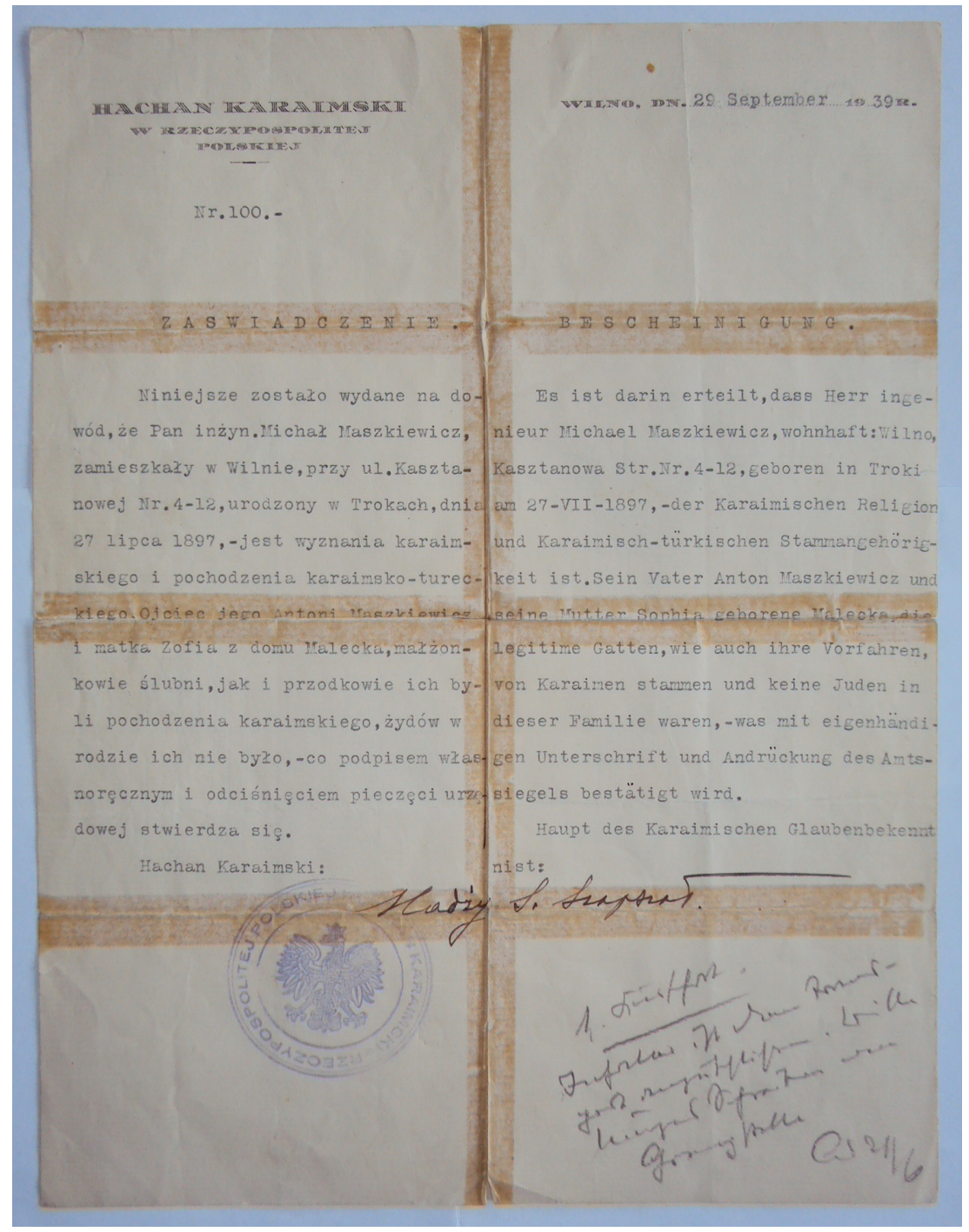

Ryc. I. Zaświadczenie nr 100 o pochodzeniu karaimskim Michała Maszkiewicza wystawione w Wilnie 29 września 1939 r. w językach polskim i niemieckim - jedno z pierwszych wystawionych dla obywateli polskich, podpisane przez hachana Seraję Szapszała (Archiwum Rodzinne). 


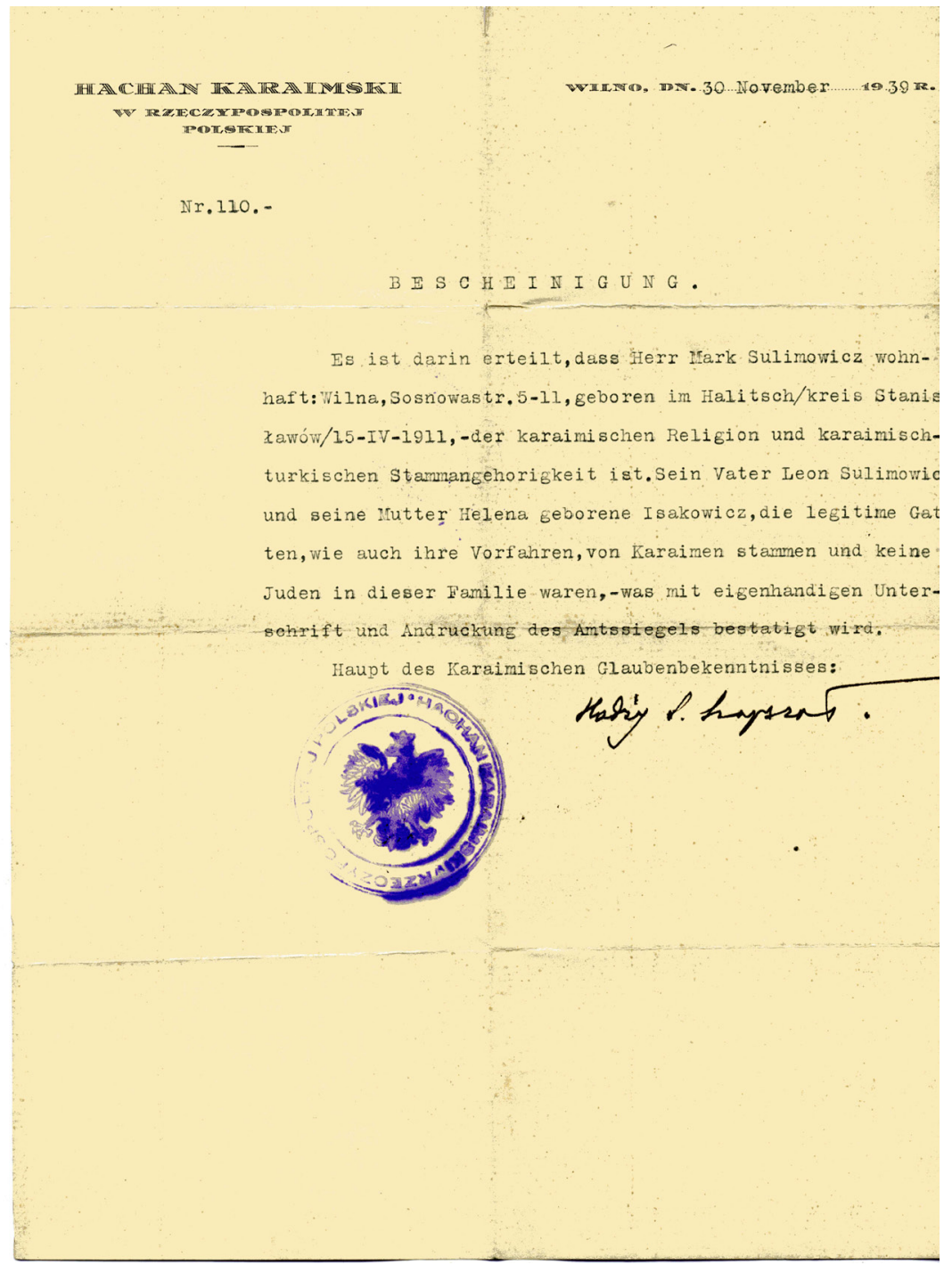

Ryc. 2. Zaświadczenie nr 110 o pochodzeniu karaimskim Marka Sulimowicza wystawione w Wilnie 30 listopada 1939 r. w języku niemieckim - podpisane przez hachana Seraję Szapszała. Marek Sulimowicz pochodził z Halicza, a w chwili wybuchu II wojny światowej mieszkał w Wilnie, nie mógł więc uzyskać zaświadczenia od hazzana gminy karaimskiej, do której należał (Archiwum Rodzinne). 
Karaimı Hazzanas

${ }_{10} 4 \mathrm{vi}$. $v_{11}$ min. $12 \mathrm{~d}$
$\mathrm{vi}_{0}-23$

Viluius, Liubarto g. $6 \mathrm{Ni}$.

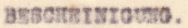

III blumah beschetnige Leh, dase

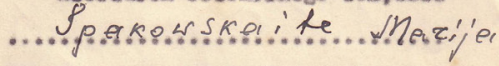

Tingepfarrter Cer koratml wohen Th-

ne ตรอ In v1lna, dev karaial ahen

Religion lot und cen ba watsohes

Tokike angehbrt.

Dess sohrotben des jastara der Relohestelle Nu ssppenforsahang in Berlin IIr 1 1110/0/17.6 - 3.9,20 vom

5.7.1939 gemses, at nd ate Karnteen niaht sla Judan ansuse ian,

¿ oblge Besoheinigung tot nuegesoben

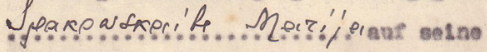
Biste, dem enteprichencen sate vorsuetellen.

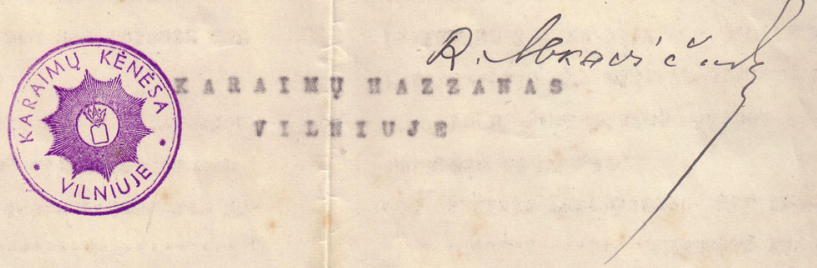

Ryc. 3. Zaświadczenie o pochodzeniu karaimskim Marii Szpakowskiej wystawione w Wilnie 12 lipca 1941 r. w językach niemieckim i litewskim - jedno z wielu wystawionych przez hazzana Rafała Abkowicza (Archiwum Rodzinne). 